\title{
Nurse Physician Relations: A Qualitative Case Study in the Emergency Department of a Hospital in Ankara, Turkey
}

Bayram Demir et Aytül Kasapoğlu

\section{Q OpenEdition \\ Journals}

Édition électronique

URL : http://journals.openedition.org/ejts/1783

DOI : $10.4000 /$ ejts. 1783

ISSN : $1773-0546$

Éditeur

EJTS

Référence électronique

Bayram Demir et Aytül Kasapoğlu, « Nurse Physician Relations: A Qualitative Case Study in the Emergency Department of a Hospital in Ankara, Turkey », European Journal of Turkish Studies [En ligne], Liste complète, mis en ligne le 31 mars 2008, consulté le 19 février 2020. URL : http:// journals.openedition.org/ejts/1783; DOI : 10.4000/ejts.1783

Ce document a été généré automatiquement le 19 février 2020.

(c) Some rights reserved / Creative Commons license 


\title{
Nurse Physician Relations: A Qualitative Case Study in the Emergency Department of a Hospital in Ankara, Turkey
}

\author{
Bayram Demir et Aytül Kasapoğlu
}

1 As it is discussed by Bourgeois (1985) and Jehn (1995), members of diverse groups hold different views as a result of their different backgrounds. This diversity often results in conflict. The level and type of conflict is very important. If constructive conflict (Van De Vliert et. al. 1999) is greater than destructive conflict, organizational effectiveness can be increased by using a problem-solving approach. As discussed by De Dreu and Van Vianen (2001), conflict management influences individual well-being, overall group performance and organizational effectiveness.

2 As a complex organization, a hospital employs personnel from various professions. Although there are many professions in this environment, two of these are central: physicians and nurses. Their interactions play an important role in providing service, along with hospital infrastructure. The social, economic and gender-based inequalities of society as a whole are felt in the hospital and there is an increased chance for the existence of various conflicts in this type of organization. If conflicts are very deep and serious, they can affect patient treatment, as well as the care and well-being of health personnel and, therefore, they can become problematic.

3 As discussed by Gerth and Mills (1969), some professions have power over others and therefore, there is a close relationship among social stratification, profession and social status. Furthermore people from different socio-economic stratas (SES) might have different tastes and values. Therefore in order to understand those differences among people one might need to know their socio-economic background in terms of social stratification. One should always remember that social relations are also power relations and subordination among people may result in conflict (Kasapoğlu 1987). It 
would not be wrong to state that investigation of the nurse-physician relationship is a good example in understanding these theoretical assumptions.

4 As discussed by Walby et al. (1994), the relationships between physicians and nurses are conventionally analyzed by sociologists within the framework of the sociology of professions. In the literature, most of the studies focus on professionalization as a struggle to get better status and advantages, such as recognition and salary. As it is argued in many studies (Aksakal et al. 1999; Türk, Çiceklioglu 2002; Çimen 2002), nurses' desire to be recognized as professional is a very important problem in Turkish society. They work hard and want to be considered more valuable and important in their work environment.

In many sociological studies, gender in terms of socialization process of a person in a given society rather than simple biological or sexual features of the person is also an important subject matter to be taken into consideration like profession or other sociodemographic variables like education. According to British sociologists (Walby et al. 1994: 59), 'there are two ways in which gender is relevant to inter-professional relations. First, the occupations are gendered, being disproportionately either male or female'. In many cases different gender within an occupation comprises a second important dimension.Walby and her colleagues accept that we are gendered in the sense of drawing on wider social patterns of conduct that may themselves be gendered.

The main purpose of this study is to understand the process of conflict and its resolution among health personnel at one hospital setting. The relationship between physicians and nurses - as well as their problems and coping strategies - are discussed.

\section{A brief information about health policies and services in Turkey}

7 In terms of health statistics, Turkey is still behind most of the developing countries in spite of the developments occurring in the country's health sector. Due to the lack of effective coordination among the Ministry of Health, social insurance institutions, university hospitals and private hospitals, effective planning services and investments are almost impossible to conduct (Ministry of Health 2003a: 13-14).

8 In the last two decades, several health reform programs have been applied by the Ministry of Health in Turkey. For example, the 'Health Transformation Program' (2003) aims to solve problems in health sector and it involves various actors, such as the state or government, universities, municipalities, foundations and associations.

The Ministry of Health in Turkey has numerous hospitals and other health facilities (Table 1), which are located in all the provinces. Every province has its own health authority which represents the Ministry of Health and acts as a regulator and supervisor of health activities within such province.

Table 1: Distribution of health facilities in Turkey (Source: Ministry of Health 2003b)

\begin{tabular}{|l|l|l|l|}
\hline Institutions & Number of Hospitals & Bed capacity & Other health facilities \\
\hline \hline Ministry of Health & 821 & 133,000 & 6,000 \\
\hline
\end{tabular}




\begin{tabular}{|l|l|l|l|}
\hline Ministry of National Defense & 42 & 15,900 & \\
\hline Universities & 50 & 26,157 & \\
\hline Municipalities & 9 & 1,389 & \\
\hline Foundations and Associations & 18 & 1,674 & \\
\hline Private & 246 & 11,824 & \\
\hline
\end{tabular}

10 Moreover, the Ministry of Health employs thousands in health staff, who work at all levels of health care. In the public health sector, approximately 300,000 health staff members have been employed. The distribution of health staff is given in Table 2.

Table 2: Distribution of health staff in Turkey (Source: Ministry of Health 2003b)

\begin{tabular}{|l|l|l|l|}
\hline Title & Turkey & Ministerial Staff & Ministerial Staff at Public Hospitals \\
\hline Specialist Physician & 43,660 & 15,868 & 15,435 \\
\hline Practitioner (Physician) & 51,530 & 31,642 & 10,528 \\
\hline Dentist & 17,108 & 3,211 & 1,912 \\
\hline Pharmacist & 22,322 & 779 & 437 \\
\hline Sanitarian & 49,324 & 34,974 & 18,764 \\
\hline Nurse & 79,059 & 45,812 & 39,199 \\
\hline Midwife & 41,513 & 37,674 & - \\
\hline
\end{tabular}

11 Nurses constitute one of the largest groups among the health staff. Midwives and nurses have the same status at the legal level, especially in hospitals. Another big group comprises physicians, namely specialists and practitioners. It would not be wrong to say that the most important duties are carried out by these health professionals in the health sector.

Working conditions, hierarchal structure and relations among health staff in the public hospitals and health facilities are regulated by the old legislations which were issued for the hospitals in 1983 by the Ministry of Health. Besides, these regulations have been adopted partially by the university and private hospitals. Therefore, organizational and work related problems of health staff in terms of division of labor and power distributions are almost the same for every institution. Legislation needs to be changed to meet the socio-economic needs like higher salary and professional needs of health staff like recognition as a independent profession and in-service training as well as job security so that they can carry out their responsibilities properly. 


\section{Methodology}

13 There are many qualitative studies in the field of health and illness (Skjorshammer 2002; La Tendresse 2000; Snelgrove, Hughes 2000) which examine conflict and job satisfaction.

Contrary to the positivistic tradition within the narrative approach, in the present study the parties' stories are considered an integral part of the conflict and solution. The study data were based on focus group interviews.

15 Most of the earlier studies focused on a single profession, i.e. nurses (Walby et. al. 1994). This research was designed as a qualitative focus group study and comparisons are made between physicians and nurses. Although there exists much quantitative research carried out mostly by health professionals (Hayran, Aksayan 1991; Yeşilkayalı 1991; Piyal et al. 2000, Bodur et al. 1996; Toraman et al. 1996; Aksakal et al. 1996; Aslan et al. 1997; Musal, Ergin 1993; Musal et al. 1995; Kurt et al. 1997; Piyal et al. 2002; Ergin 1996; Gündoğmuş et al. 2004; Yıldırım et al. 2005), this is one of the pioneering studies based on qualitative data in the field of sociology of health and illness - which is one of the less developed fields of sociology in Turkey. According to the one assessment the percentage of sociological studies in the field of health and illness is very low (5\%) and there are a limited number of sociologists interested in this subject (Kasapoğlu 2000). Therefore, it would be quite accurate to state that most of the Turkish sociologists are not aware of the importance of the field and thus do not conduct studies on health issues.

16 The universe of the research was the emergency department of a state hospital in Ankara. The hospital was established in 1979 to provide emergency services for traffic accident victims from central Anatolia. In the emergency department, there were 30 health personnel, 17 of which were physicians. Although this hospital contains all necessary units that would be present in any hospital, the present study was carried out in the emergency services department. Due to the nature of the services this department provides to the patient, its staff is supposed to work in close collaboration.

\section{Procedure}

17 Prior to beginning the research, researchers submitted the necessary requests for permissions to the hospital management. After the assessment of the Ethic Committee, the submission was approved.

18 As a qualitative research tool, focus groups provide many advantages despite their limitations (Stewart, Shamdasani 1990; Madriz 1998). There were two stages of data collection. First, there was a meeting conducted with the nurses and secondly, there was another with the physicians. In a one week period, two separate focus group meetings were carried out and interviews were taped after gaining approval from the subjects.

19 The meeting room was 16 square meters with seven chairs and one round table. There were no phones or other distractions located within the space. The interviews were recorded on tape and the transcription work took over 12 hours for each meeting. 
Focus group participants had the objectives of the study explained carefully to them. To remind them of the study date and time, researchers telephoned the participants. Nine of the 13 nurses accepted our invitation. Later, due to job intensity, only six of them participated in this voluntary study. Almost the same pattern was observed for the physicians: nine out of 17 accepted, but then only six of them participated. As it is the case in similar environments all over the world, these professionals are busy and their time is limited.

21 The group was run with the asking of questions that required a low level of moderation. The moderator was always very careful to make people speak without deviating from the subject at hand. In order to compare findings, similar questions were used in both focus group meetings.

The meeting room was 16 square meters with seven chairs and one round table. There were no phones or other distractions located within the space. The interviews were recorded on tape and the transcription work took over 12 hours for each meeting.

This study was carried out under the principle of 'unity of opposites'. From the beginning, researchers assumed that everything was contextual, and therefore, they looked for dualities such as the existence of peace and conflict unfolding at the same time. In 'formal logic' there is always one right answer; there is no possibility for a second or third solution. However, this kind of logical approach does not suffice to understand and interpret the complexity of social life. Therefore the researchers of this study adopted the main principles of dialectics (Kasapoğlu 1999; Kasapoğlu, Ecevit 2004) to understand the hybrid nature of the social facts.

\section{First focus group: nurses}

When the nurses arrived for the discussion we had them sit around a table facing one another. There were six participants and the focus group interview lasted about two hours. Since each nurse had more than five years of work experience, it was easy for them to answer the questions. After reminding the participants of the subject matter for the study, the moderator also explained both the format and objective of the meeting itself. It had been previously decided by the researchers not to ask any questions about 'problems'. Wording is very important and the researchers wanted them to talk about what was important to them, not to simply answer the questions in a mechanical way. Their answers were mostly focused on communication with physicians and their authoritarian attitudes and behaviors toward nurses.

Moderator: What makes you most uncomfortable in your job?

N. F. (female): There is something wrong. There is a problem with physicians not referring to us in a professional manner. For example, rather than addressing us as 'hemşire hanım' (Madam the nurse), they often refer to us by using our first names.

N. E. (female): I also want to see professional respect practiced by physicians towards the nurses. In other words, I want to be called 'hemşire hanım', too. Communication is important to me as well.

N.B. (female): Physicians should remember who they are. They do their job professionally and nurses do as well. This is what I think. We should not take these things personally or worry about issues of superiority and inferiority. Although we 
run into these situations frequently, we will still do our job following the physicians' instructions. This is our job. I believe we must not look at it with a concern about superiority and inferiority. In other words, we must view this situation professionally. They do their job and we do our job. As my friends said, we should be able to address them casually as they address us, but we never do it.

Moderator: O.K. What is the matter? Why you are not able to do it?

N. B. (female): It has always been that way. Physicians see themselves as superior. It should not be that way, but it is.

N. B. (female): The only problem I have with being called by my first name is that when I address the physician formally he is responding personally. In other words, we do not speak to one another in the same way and with the same respect. I call him 'doktor bey' (Sir the physician) but he responds to me by saying, '[her first name], come and do this!' which is not nice.

There have been long been serious discussions as whether nursing ought to accept a clearly subordinate role to medicine or whether it can assert itself as an independent profession with a less unequal status with respect to medicine (Walby et al.1994). In the focus group, participants were basically talking about the same problems as Walby pointed out this issue when she was discussing independency of nursing profession from medical doctors. Nurses indicated that they want to work more independently.

Another factor contributing to the stress level is the education level. Due to the fact that nurses have relatively less education than the physicians they work with, they become the subordinates within the team. In Turkey, most nurses have completed only vocational education training for four years. It appears that this trend will continue because vocational high schools remain open and still accept students, such as nursing candidates. As discussed by Ritzer (1972), since they do not have university degrees, nurses are still under the control of others and subordinate to physicians.

N. A. (female): Beginning the profession at an early age (18) without clearly developed self-confidence and trying to carry out important responsibilities forces us to work under pressure. The status of nursing is the same all over in Turkey... Why? It is because nursing is not accepted neither here in the city nor in the rural areas. When we face these kinds of problems, they try to solve the issue by frequently changing our workplace. But physicians stay in the same place...

N. F. (female): There is something wrong in the system. We are degraded as auxiliary health personnel and we do not have the right to specialize. We are treated differently than physicians. But our work requires teamwork and we are dependent on each other. To classify professions according to superiority is not fair. Nursing is a profession, just like being physician. I do not accept being classified in the category of auxiliary health personnel. Nursing must be recognized as a profession. At least, this is how I feel. This is mainly due to the educational system and politics in Turkey. They do not provide us with university education in order to improve our status. They always create barriers. In other words, we do not have many incentives. Rather than motivating us, they are always blocking us. [The government] has closed our schools. It is almost the same in our hospital and there are not many opportunities. 
They see you as a second-class citizen. In the first level are the physicians then come the nurses and, finally, the other personnel. Is that good?

N. L. (female): I absolutely agree with my friend's ideas. I do not believe that we are working as professionals. Only in certain departments we do have an opportunity to apply our profession positively.

N. E. (female): It seems the same to me. Nurses are seen as auxiliary health personnel. I want a better educational system and not to be called 'auxiliary health personnel' anymore...

Moderator: There is a division of labor. Physicians order the treatment and you are responsible for application and care. What is the matter then?

N. E. (female): Physicians must not interfere with patient care. They should only give the treatment. We can take care of both treatment and care.

N. A. (female): According to the definition of nursing, we see patients as a whole. After their diagnosis, physicians give their orders for treatment. But physicians do not use a holistic approach. Rather, they focus only on the sick part of the body. We, on the other hand, provide 24 hours service for them.

Moderator: You mean that there is no balance between your responsibilities and roles.

N. A. (female): Yes, there is not. of course, we are dependent on physicians' orders. Our job is not only measuring blood pressure or giving injections and then leaving the patients alone. Sometimes, if we know the patients' history, we give a Novalgine injection (a kind of medicine to lessen the fever) or apply a cold pack. If the fever continues, we inform the physician. Then, further analyses are carried out according to the physicians' order. For example, taking a throat culture.

N. F. (female): It seems to me that if you have enough information about the patient and understand why the fever is increasing, without informing the physician, if you give the Novalgine injection you are acting within the bounds of your profession. Without asking the physician why the patient has a fever, we should know what to do. We should ask ourselves: what can we do for this patient? But we are always working within a physician-centered environment.

N. B. (female): I observed these kinds of things in this hospital and in other places. We do not work like professionals; we wash devices, prepare tampons and also clean our offices...

In accordance with other studies (Davies 1980; Gamanikov 1978; Mackay 1989, 1993; Stacey 1988), the findings of this research revealed that power distribution is a key concept, and that controlling others is the main purpose for conducting daily routines and achieving organizational targets, as well as the fulfillment of personal desires.

Besides, there is another matter to be considered: gender. As posed by Lorber (1990), 'would women physicians identify with the role of the nurse more than male physicians, or alternatively more strongly assert professional difference to distance themselves from the lower status position?' was an important question. In our focus group study, some challenging findings emerged. According to Walby (1994), the influence of the gender of an individual physician or nurse on inter-professional conflict was very slight. There was no statistically significant difference in the reporting of conflict or anger with respect to other professions. Besides, in day-to-day 
work, gender is far more of a significant factor within professions rather than between them (Walby 1994). In other words, there is conflict between female and male nurses in the nursing profession. But contrary to this theory, in the Turkish case, the relationship between female physicians and female nurses is more problematic and therefore quite different.

Moderator: Let's talk about your relationship with the other gender in work situations.

N. L. (female): I have been a government officer for eight years. I was happier working with male physicians during those years. Female physicians are more 'kaprisli' (capricious) and, therefore, the working situation becomes uncomfortable. When they wanted me to do something, they gave rude orders and they saw themselves as our superiors... I hardly experienced the same manner from male physicians. They are mostly more polite.

N. F. (female): I mean that working with female physicians is harder than with male physicians...

Moderator: What makes you think that way?

N. F. (female): In our culture, during the socialization period, parents always keep saying that 'my daughter or my son will be a physician when he grows up'. Such people are spoiled from childhood and, as soon as they become physicians, they see themselves as if superior and also think that they know everything. This attitude is common for both sexes, but females have it to a higher degree than males.

N. A. (female): Females are more 'kaprisli'. Working with male physicians is easier because they always try to finish their job or to solve the problem as soon as possible.

N. C. (female): It seems to me that it is a problem of personality. There is no difference between genders.

N. E. (female): According to me, although we are the same gender, lady physicians are 'kaprisli'...

Moderator: Do you think that lady physicians reflect more?

N. E. (female): Although they do not want to reflect, they do...

28 At this point it would be helpful to remember that there are different models of the balance between the elements of hierarchy (including gender) and symbiosis in the relationships among health personnel. For example, in the Salmon Report (cited in Walby 1994), symbiosis takes priority over dominance or hierarchy. A second model of stress subordinates relationships between the physicians and the nurses. Here, the nurse is the assistant to the physicians, a member of the hospital staff that is considered to fall under the category of auxiliary subordinate occupations. Finally, the third model lies somewhat between these two and assumes that there is simultaneously both hierarchic and symbiotic interdependence based on expertise. Physicians and nurses have different functions but there is also ambiguity among the functions in terms of which functions are superior to others (Walby et al. 1994: 57-58).

The function of a physician is to diagnose and treat. The function of the nurse is to care. But this situation can also be interpreted as hierarchic. While physicians are diagnosing illness, nurses follow physicians' instructions. And as discussed by Walby et al. (1994), the function that physicians fulfill partially defines what nurses do. Nurses therefore do not have much flexibility. They are almost always restricted by the orders 
of a physician. As a result, physicians have dominance on the other health personnel and for the most part on nurses. Most conflicts are derived from undefined professional boundaries. Relevant to the above discussion, participants' views on these subordination or hierarchic relations were as follows.

Moderator: During your work what kind of situations do you face the most?

N. B. (female): Some physicians have a kind of 'style'. For example, as soon as a patient arrives, some physicians - before conducting a physical examination - want to directly make analyses, i.e. ECG (electrocardiograph, to record the electrical discharges produced by heart tissue), bio-chemistry, or blood test. We believe that physicians should first examine the patient's physical conditions and then ask us to conduct the analyses. Therefore, physicians' desires seem to us as being 'forced labor' because according to us there is no reason to ask for the tests before the patient examination...

Moderator: How do you feel then?

N. B. (female): Of course we feel stress and we try to live with it. But I believe that I am doing unnecessary things.

Moderator: O.K. Are you discussing these issues with physicians?

N. B. (female): We do not. We only talk about these issues among nurses. We do not share our thoughts with physicians. We generally do not talk, but actually once I talked to one physician. And his answer was: 'I do not do that'.

Moderator: Are you telling this to physicians?

N. B. (female): We should tell them but we are afraid of their reactions.

N. F. (female): Physicians lack knowledge, also. As nurses, we experience their problems as well. Since physicians do not know what to do and what is the sickness or the case they are dealing with, they immediately push you into the middle of chaos. For example, they first request a blood test and 10 minutes later they want a bio-chemical analysis. And you are the one who is always coming face to face with the patient. When I take their blood a second time, patients get angry and ask you why you are doing that as you had already taken blood a few minutes ago. While patients are suffering on one side we find ourselves in the middle and physicians are always operating outside of this hectic situation.

Moderator: If your approach to cases is different from the physicians', what do you do?

N. F. (female): If I believe the treatment is wrong, I react by saying, 'I do not do it'.

Moderator: Did you ever say it?

N. F. (female): Yes I did. Mostly I say this during the treatment. But in the case of other orders such as taking blood, I do not question his attitude directly. During treatment and in similar situations, I think it is harmful to a patient's life, or when you have an IV (intravenous) flooding you can make your intervention. At least if he orders a more than necessary amount of medication to be administered to the IV, I do remind him that it is too much.

Moderator: You tell it to whom?

N. F. (female): If the physician knows what to do there is no need to say anything. When I talk to him, if he agrees with me, we achieve consensus. 
N. A. (female): I will give you an example. Sometimes we discuss the treatment process with physicians. For example last year, a physician brought an IV for a patient without checking the bottle. Although luckily nothing happened to the patient, it created a big problem for the nurse and not for the physician, which is unfair. Another example was that medicine which is not allowed in an IV was ordered by mistake. The nurse who administered it without checking the order was found responsible and therefore guilty. She was punished. What I mean is that it is imperative that we always be alert.

Moderator: What do you do if you have different ideas from physicians?

N. C. (female): I defend my idea if I know the subject well. If I have information about the medicine and pills I discuss and defend my decision. If I do not know the case very well I just raise my hesitations or worries.

Moderator: Did you ever take the initiative with respect to stating that the physicians' knowledge is not sufficient for treatment?

N. C. (female): Of course I do. But by consulting another physician first about the treatment or saying: 'that physician is doing this and this... what do you say?' Mostly I consult more senior physicians.

N. L. (female): In one case, a physician ordered 'two Buscopans' (muscle relaxant) and one and half ampoule of Novalgine (pain reliever). This seemed wrong to me. At that time the patient's blood pressure was 90/60. In other words, it was quite low. These medicines were too much and I was not able to administer them intravenously. I asked another physician who was a more senior physician. Unfortunately, he did not want to interfere and he told me: 'You must do it'. Later on, I administered one by IM (intramuscularly) and the other by IV, but the physician thought that I had done it the way I was told.

Moderator: You did not discuss it with the physician.

N. L. (female): I did not discuss it because I knew him quite well and I knew he would insist on me following his first order.

N. B. (female): One physician ordered me to give some medicine by IV for a patient whose vein was open. But I told him that there was a written instruction on the box of medicine saying that it must be given by IM. And the physician said, 'O.K. Do it by IM'. In fact, I guess, in similar matters if we remind physicians of these things they usually accept. I also believe that if we tell them about our concern at the time of the incident there is more of a possibility for them to do the right thing.

Moderator: What are physicians' reactions when you make an error?

N. B. (female): There was a patient with high blood pressure. I had to open his vein. And the physician asked me to use arm veins. I tried using the patient's hand. But the veins were very thin and suddenly the vein blew out. The physician got angry with me. At that moment, I did not say anything but I still believe that the physician was wrong.

N. A. (female): We discussed and solved the problem; it is mostly a matter of tolerance. 
N. E. (female): I remember there was a physician and he never trusted the nurses. He was always controlling nurses, preventing them from doing their work with the patients...

N. F. (female): We must be very alert and careful. At the place in which I used to work, one nurse was fired because of the wrong application of one injectable medicine.

In order to provide more comprehensive data, the findings of the second focus group carried out with physicians are presented below.

\section{Second focus group: physicians}

31 There were six practitioners, two females ( $C$ and F) and four males ( $A, G, M, U$ ), who all worked together at the same hospital emergency service. As mentioned before, their work experience was greater than five years but not in the same hospital. The focus group interview lasted about half an hour. Similarly to the nursing interview, the same meeting room was used and the same steps were followed. The physicians' answers were very similar to the nurses'. It seemed that both sides were aware of the climate in which they live.

Moderator: Let's talk about issues bothering you...

Dr. M. (male): In working situations, when I review from the past to the present, the thing that most bothers me is unawareness... Actually this is true for both sides either physicians or nurses. Unless there is a defined status, it is natural. If people are not aware of their status, conflicts occur naturally from time to time. Personally I have not experienced many conflicts. Actually it is because of my personality... But sometimes conflict is unavoidable. I believe that the only way to overcome such problems is to define the responsibilities of our task and understand each others' status.

Dr. U. (male): At the beginning, peoples' laziness was making me mad.

Dr. C. (female): I agree with my colleague. There is a problem with status. Since we are here as practitioners, nurses do not want to accept that they are our subordinates.

Dr. F. (female): When we talk about personnel... I do not consider only the nurses and I agree with my friend. They can be ordinary cleaners. Sometimes they interpret our friendly behaviors incorrectly.

Dr. G. (male): Lack of productivity bothers me the most. We do not work in this hospital. Unfortunately, our work here just looks like that of the traffic police. What we see here are almost the same general problems experienced in other hospitals in Turkey.

Dr. M. (male): I would like to talk about physician-nurse relationships. There are important problems originating from wrong socialization.

Moderator: How do you evaluate your conditions in the hospital?

Dr. M. (male): I see the patients first. If there are no patients, our functions become zero. If we ask, why are physicians first? The answer is because we are the people who are leading patient care. 
Dr. A. (male): As physicians, if we accept the reality that we are employed to save lives, most of the problems will be solved. Another important issue is auxiliary health personnel... Now I do not want mention her name, but one day she told me that she does not accept the title of 'auxiliary health personnel'. According to me, it does not change the reality of their existence as auxiliary heath personnel. Auxiliary health personnel are assistants to the physicians. This does not necessarily mean that they are the slaves of physicians. Their task is to help or to assist physicians and work in accordance with this division of labor. If you become aware of the situation, there will be no problem any more. Physicians will do their job, nurses will do their job. In fact, there is not much difference; we are part of the same job and at the same time there is independence. Physicians give the order and auxiliary health personnel, by following orders, try to complete this task...

Dr. U. (male): There are some uncertain things about physicians' status. Physicians are not understood properly.

Dr. F. (female): I also blame us because there is something wrong in our education. We have been educated as auxiliary health personnel, rather than physicians. I was treated as a doormat in university. I did everything except window cleaning.

Moderator: Let's talk about how you feel when you work under these difficult conditions. Will you please give us an example?

Dr. U. (male): For example, nurses start to provide services or help to the patients immediately like in 30 seconds after their arrival in the hospital.

Moderator: What happens then?

Dr. U. (male): At that moment, when you try to tell the patient: 'we will immediately treat you', the patient says: 'Yes, I am waiting'. I am also still waiting for the nurse and at the same time, of course, I tell the patient: 'As soon as your blood pressure is measured I will examine you'. Believe it or not... in emergency service one minute seems to me an hour. On the other hand, sometimes, we, physicians do the same things and that is unfair too.

Dr. C. (female): The most important problem is that they do not have high commitment to work.

Dr. F. (female): I believe the source of most problems is personal.

Dr. G. (male): Sometimes my level of adrenalin increases especially if there are many patients. If I repeat my orders and see they are still not followed I get nervous. But I have never discussed this with anyone... Roles of the physicians and nurses are clearly defined. As a team we treat the patient. Physicians decide what has to be done...

Dr. M. (male): There is always stress in physicians and auxiliary health personnel relations. I feel it. I also believe that the others do as well... Actually I do not feel much, but the reality is that the auxiliary health personnel are always trying to find our mistakes. There is always a hidden competition. I noticed it several times. In other words, nurses tell me that 'one of your friends made this and this...' The same things are also valid for physicians... 
Moderator: Did you ever have an experience with different approaches towards your treatment? If so, how did you react?

Dr. M. (male): It was not about my treatment but I remember when a nurse came one day and asked 'these mistakes are done, so what can we do?' she was not able to tell directly the one who made the mistake. I understand and I accept these things as normal.

Moderator: When you said, I see this as normal, what do you mean? What did you do in that case?

Dr. M. (male): We accepted the mistake and tried to solve the problem. Actually someone did something very wrong. It was wrong but it was done unintentionally... I believe that the most important thing is being constructive...

Moderator: How do you feel when nurses raise their opposition?

Dr. G. (male): During treatment, if a nurse reminds me of something I accept it very naturally. I do not see it as an intervention. But I evaluate her entire behavior and attitude toward me. Body language is also important to me. If she tries to focus on my faults, this is intolerable. But just friendly warnings are very good. In my case, I ordered her to dispense Dicloran. She said 'no'. I asked why? She said, 'You ordered it by IV. But IM is written in the drug information'. Lady Nurse (he was teasing) did not want to take responsibility and risk. Many times I ordered the medicine administered but she refused again. As a result I did. And nothing happened. (The other physicians were laughing!!!) What I mean is that I do not like to show emotional reactions. But general attitudes are very important to me. For example, when a young physician comes they take advantage of his youth and inexperience. Mostly, nurses may order him around, 'Do this and do that'. These behaviors are a shame and I do not think this is appropriate behavior. In other words, understanding is very important to me.

Dr. M. (male): Nurses' warnings are very natural, but their manner is very important. For example, unless it is very urgent these warnings must not be given in front of the patients. If we try to humiliate each other in front of the patient it is a shame. Although the nurse is absolutely right, I discuss it with her.

Dr. U. (male): It seems to me that manner is more important than the content. First, this warning must not be in front of patients. Secondly, it must be good... She has the right to intervene with my treatment, but place and manner are very important.

Moderator: If the nurse makes a mistake or a fault, how do you react? What do you do then?

Dr. U. (male): Immediately react. But gently and friendly by paying attention to the place.

Dr. M (male): I am absolutely against gossip. Talking about nurses and physicians' shortcomings is a shame.

Dr. A. (male): One day a patient came with kidney problem.We opened his vein and gave him a serum. I told nurses to give 3-5 Buscopan. One of them reacted as, "what do you mean?' and continued, 'if you insist on this amount of medicine you should give me a written order, otherwise I do not take responsibility'. I guess at that time I was mistaken. I just told them 'give 3-5 Buscopan' unconsciously. Of course, they would watch the serum. Later on we solved the problem. I must admit that at the beginning I got angry with that nurse because she should not have reacted as she did. 
I do not like to discuss my orders with nurses especially in front of the patients. I thought one minute what I should do. And I said O.K. But I was really nervous at that moment. I wrote the order and left the ward. Half an hour later when I came back my order was still there and nothing had been done as yet. I said to the nurse: 'I will report your behavior to the administration since it has been half an hour and you have not checked my order'. The nurse understood that it was her fault. The incident ended happily.

Dr. U. (male): There has been always hidden competition and conflict between nurses and physicians. Nurses bring and reflect their problems into their job...

Moderator: Well...

Dr. U. (male): I have another view that I want to share with all of you. When I review my entire professional life, conflicts have been more among female nurses and female physicians. The ratio of conflicts is higher in the same gender. The predictor of this situation can be women's self identity, insofar as seeing themselves superiors. When they compare themselves with nurses, female physicians tend to see themselves or consider themselves at a higher status than nurses.

\section{Conclusion}

The sociology of professions and its basic concept of 'division of labour,' which is developed by Durkheim, are mostly derived from 'professional differentiation'. Furthermore, according to Durkheim, main problems in the society are mostly social and ethical rather than economical (cited in Aron 1986). Contrary to Durkheimian terminology there are also some views that professions or occupations are established by economical roles which can be also part of the entire economic system (Gerth and Mills 1969:308). In this study it is assumed that social and economic factors are mutually inclusive. Therefore, in reality, the combination of both views is valid. In other words, both social and economical factors play important roles in the social organization of hospitals.

However, one thing that was not discussed in detail in our study was 'pay satisfaction' (Lee and Farh 1999), which is very important. The economic and financial difficulties that Turkey is currently experiencing result in many complaints among many workers, including nurses who do not have a chance to earn extra money from private patient care, like physicians do. Most of them are living in peri-urban areas and they pay extra energy to survive. This is a really important structural factor, but in order to stay focused on a specific subject, we avoided including it.

Job satisfaction of health personnel is very important. A recent study on mood and emotion included job satisfaction research as the missing piece (Fisher 2000). In the present study, physicians and nurses were not satisfied with their job, and their emotions and moods play an important role on the quality of service they provide.

Nurses' desires for more autonomy in the workplace may create problems. As discussed in Langfred (2000), there is a paradox between individual and group level autonomy in work groups. Due to the fact that autonomy is either at the individual or group level, it directly impacts group cohesiveness and also indirectly influences group effectiveness. These are both undesirable side effects in the field of health because of the potential 
risks on the patients' lives. Nurses in this study perceive a lack of autonomy and this creates major stress for them.

Consultation with managers (Yukl and Fu 1999) was important in our study. Nurses were consulting senior physicians about their problems with less experienced physicians. Personal or professional, both kinds of consultation played a kind of role for conflict resolution by developing communication channels among personnel.

In developing countries such as Turkey, women have less opportunity to get a better education. Female professionals, unless they are very motivated, do not have much opportunity to achieve certain degrees (Dayığlu 1995). Therefore, they are more ambitious and less able to tolerate their team members, i.e., female nurses. Thus, female physicians' attitudes toward nurses can be interpreted as unusual and it requires time to develop more institutionalized relations with nurses.

In this study, female physicians as leaders were found to be emotional and, therefore, less effective than male physicians. This finding is similar to Lewis's (2002) study, which examines how followers respond to negative emotional expressions of male and female leaders. Female physicians' expressions, as discussed by Parkes (1985) and Narayanan et al. (1999), could also be similar to that. Women may experience stress because expression of emotionality is gendered within organizations.

Contrary to the Turkish case, in Britain, female physicians were used to struggling for their rights along with nurses against the dominance of traditional male centered medicine. Since historically, in this context, medicine is a male dominated field and both female physicians and nurses had experienced similar subordinated relations, this could generate gender based cooperation among them.

As a conclusion, the professional relations among nurses and physicians do not constitute a simple hierarchical relationship as Walby and her colleagues (1994) discussed. It becomes much more complicated, especially in different cultures and society. Personal, professional, economic and gender based inequalities all together create conflict and stress. However, there were also conflict management techniques developed to make the workplace sustainable and, therefore, productive in terms of the health services they provided. On the other hand, it was a comprehensive process, not the simple static situation that we observed. In the hospital, there were dynamic relations among personnel. They were discussing or reacting, but then they developed a method to solve their problem before continuing to work again. There was a kind of flexible structure in which nurses, because of their knowledge and experience, were quite powerful. Regardless of gender, some physicians were suffering from nurses' reactions or negative attitudes towards them. It was not a simple one sided game; there were sides competing against each other actively. In other words, although nurses were subordinates, it seems to us that they were also sharing physicians' powers and treatment (Sculpher et al. 2002), at least in this particular department in the hospital.

41 Therefore, more than duality we observed 'hybrid' (Alund 1999) structures and relations. But these are only subjective interpretations based on limited qualitative study and require more comprehensive studies. We strongly recommend conducting more focus group discussions on the different departments of private hospitals, as well as the state hospitals. 


\section{BIBLIOGRAPHIE}

Aksakal, N.F.; Özkan, S.; Baykan, Z.; Aycan, S. (1999) ‘Gölbaşı Bölgesi’nde Birinci Basamak sağlık Kuruluşlarında Çalışan Sağlık Personelinin Mesleki Memnuniyet Durumları' Job Satisfaction of Health Personnel in Service in Primary Health-Care Centers in Gölbaşı region], Sağlk ve Toplum 9, pp. 9-14.

Alund, A. (1999) 'Ethnicity, Multiculturalism and the Problem of Culture', European Sociology 1, pp. 105-116.

Aron, R. (1986) Main Currents in Sociological Thought: Durkheim, Pareto and Weber, Ankara, İşbank Publications.

Aslan, S.H.; Aslan, R.O.; Kesepara, C.; Alparslan, Z.N.; Ünal, M. (1997) ‘Kocaeli’nde Bir Grup Sağlık Çalışanında İşe Bağlı Gerginlik, Tükenme ve İş Doyumu' [Work Related Strain, Burn-Out and Work Satisfaction among a Group of Health Professionals in Kocaeli], Toplum ve Hekim 12, pp. 24-29.

Bodur, S.; Güler, S.; Güler, S. (1997) (Sağlık Yöneticilerinde İș Doyumu' [Job Satisfaction among Health Administrators], Genel Tip Dergisi 7, pp.189-193.

Bourgeois, L.J. (1985) ‘Strategic Goals, Environmental Uncertainty and Economic Performance in Volatile Environments', Academy of Management Journal 25, pp. 548-573.

Çimen, M. (2002) 'An Important Problem for Health Personnel, Role Conflicts and Role Ambiguity', Health and Society 12, pp. 87-93.

Davies, C. (1980) Rewriting Nursing History, London, Croom Helm.

Dayığlu, N. (1995) Earnings in Equality Between Genders in Turkey, Unpublished Ph.D. Thesis, Ankara, METU.

De Dreu, C. K.W.; Van Vianen, A. E.M. (2001) 'Managing Relationship Conflict and the Effectiveness of Organizational Teams', Journal of Organizational Behavior 22, pp. 309-328.

Ergin, C. (1996) ‘Sağlık Personelinin İş Anlayışları ve Tutumları Araştırması' [Job Attitudes and Perceptions of Health Personnel], T.C. Sağlık Bakanlığı Sağlık Projesi Genel Koordinatörlügüu, Ankara.

Fisher, C. D. (2000) 'Mood and Emotions while Working: Missing Pieces of Job Satisfaction', Journal of Organizational Behavior 21, pp. 185-202.

Gamanikow, E. (1978) ‘Sexual Division of Labor: the Case of Nursing', in Kuhn, Annette; Wolpe, Ann-Marie (eds.) Feminism and Materialism, London, Routledge, pp. 96-123.

Gerth, H.; Mills, C.R. (1969) Character and Social Structure, London, Routledge.

Gündoğmuş, Ü. N.; Özkara, E.; Mete, S. (2004) 'Nursing and Midwifery Malpractice in Turkey Based on the Higher Health Council Records', Nursing Ethics 11, pp. 489-499.

Hayran, O.; Aksayan S., (1991) 'Pratisyen Hekimlerde İş Doyumu' [Job Satisfaction of General Practioners], Toplum ve Hekim 47, pp. 16-17.

Jehn,K.A. (1995) 'A Multimethod Examination of the Benefits and Detriments of Intragroup Conflict', Administrative Science Quarterly 40, pp. 256-282. 
Kasapoğlu, A. (1987) ‘Medical Education from Sociological Point of View’, TODAIE Journal 20, pp. 3-13.

Kasapoğlu, A. (1999) 'Understanding the Society-Culture Relationship', Paper presented in Symposium on the Social History of East and South Eastern Anatolia, Van, Turkey, 16-18 June (unpublished).

Kasapoğlu, A. (2005) ‘The Study of Sociology in Higher Education', International Education Journal 6, pp. 537-546.

Kasapoğlu, A.; Ecevit, M. (2004) ‘Culture and Social Structure: Identity in Turkey', Human Studies 27, pp. 137-167.

Kurt, M.; Yüksel, İ.; Yüksel, M. (1997) ‘Hekimlerin İş Güçlüğü Faktörlerinin Belirlenmesi ve İş Doyumu, İş Gerilimi, Örgütsel Bağlılık Üzerindeki Etkisinin Analizi’ [Determination of Job Difficulty Factors of Physicians and Analysis of Impact of These Factors on job Satisfaction, Job Tension and Organizational Commitment], Toplum ve Hekim 12, pp. 2-9.

La Tendresse, D. (2000) 'Social Identity and Intergroup Relations within the Hospital', Journal of Social Distress and Homeless 9, pp. 51-69.

Langfred, C. W. (2000) 'The Paradox of Self Management: Individual and Group Autonomy in Work Groups', Journal of Organizational Behavior 21, pp. 563-585.

Lee,C.; Farh J.L. (1999) ‘The Effects of Gender in Organizational Justice Perception', Journal of Organizational Behavior 20, pp. 133-143.

Lewis, K. M. (2000) 'When Leaders Display Emotion: How Followers Respond to Negative Emotional Expression of Male and Female Leaders', Journal of Organizational Behavior 21, pp. 221-234.

Lorber, J. (1991) 'Can Women Physicians Ever Be Equal in the American Medical Profession?' in Helena Z. Lopata (ed.) Current Research in Occupations and Professions, Greenwich, C.T., JAI Press 6, pp. 25-37.

Mackay, L. (1989) Nursing a Problem, Milton Keynes, Open University Press.

Mackay, L. (1993) Physicians and Nurses: Working Together, Edinburgh, Churchill Macmillan.

Madriz, E. (1998) ‘Using Focus Groups with Lower Socioeconomic Status Latina Women', Qualitative Inquiry 4, pp. 114-128.

Manley, J. E. (2000) 'Negotiating Quality: Total Quality Management and the Complexities of Transforming Professional Organizations’ Sociological Forum 35, pp. 457-480.

Ministry of Health (2003 a.) Transformation in Health, Ankara, Ministry of Health Publication.

Ministry of Health (2003 b.) Health Statistics, Ankara, Ministry of Health Publication.

Musal, B.; Elçi, Ö.ç.; Ergin, S. (1995) ‘Uzman Hekimlerde Mesleki Doyum' [Job Satisfaction of Consultants], Toplum ve Hekim 10, pp. 2-7.

Musal, B.; Ergin, S. (1993) 'Pratisyen Hekimlerde Mesleki Doyum ve Etkileyen Faktörlerin Belirlenmesi' [Determination of Factors Affecting Job Satisfaction of General Practioners], Toplum ve Hekim 54, pp. 22-25.

Narayanan, L.; Menon, S.; Spector, P.E. (1999) 'Stress in the Workplace: A Comparison of Gender and Occupations', Journal of Organizational Behavior 20, pp. 63-73. 
Piyal, B.; Çelen, Ü.; şahin, N.; Piyal, B. (2000) ‘Ankara Üniversitesi Tıp Fakültesi Hastanesinde Çalışanların İş Doyumu' ['Job Satisfaction of Health Care Workers of Ankara University Faculty of Medicine Hospital], Ankara Üniversitesi Tıp Fakültesi Mecmuası 53, pp. 241-250.

Piyal, B.; Piyal, B.; Yavuz, İ.; Yavuz, A. (2002) ‘Sosyal Sigortalar Kurumu Ankara Eğitim Hastanesi'nde Çalışanların İş Doyumunu Etkileyen Etmenler' [Factors Affecting Job Satisfaction of Social Insurance Institution's Ankara Education Hospital's Health Care Workers], Kriz Dergisi 10, pp. 45-56.

Ritzer, G. (1972) Man and His Work: Conflict and Change, New York, Meredith Corporation.

Skjorshammer, M. (2002) 'Understanding Conflict Between Health Professionals A Narrative Approach', Qualitative Health Research 12, pp. 915-931.

Snelgrove, S.; Hughes, D. (2000) 'Interprofessional Relations between Physicians and Nurses: Perspectives from South Wales', Journal of Advanced Nursing 31, pp. 661-667.

Stacey, M. (1988) The Sociology of Health and Healing, London, Unwin Hyman.

Stewart,W.D.; Shamdasani, N. (1990) Focus Groups: Theory and Practice, London, Sage.

Toraman, A.R.; Demir, C.; Güçlü, A.K.; Cankul, H.I.; Özaltın, H. (1996) 'Hekim ve Hemşireleri Hastaneye Bağlayan-Uzaklaştıran Faktörler' [Loyalty and Exit Factors of Nurses and Physicians to a Hospital], Ulusal Halk Sağlığı Kongresi Kitabı, Istanbul, pp. 269-273.

Türk, M.; Çiceklioğlu, M. (2002) 'Determination of In-Service Education Priorities of Midwifes/ Nurses Working in Bornova Health District' Health and Society 12, pp. 63-68.

Van De Vliert, E.; Nauta A.; Giebels, E.; Janssen, O. (1999) 'Constructive Conflict', Journal of Organizational Behavior 20, pp. 475-491.

Walby, S.; Greenwell, J.; Mackay, L.; Soothill, K. (1994) Medicine and Nursing: Professions in Changing Health Service, London, Sage Publication.

Yeşilkayalı, H. (1991) 'Acil Polikliniklerde Çalışan Hekimin Konumu' [The Position of General Practioners who Work in Emergency Departments], Toplum ve Hekim 47, pp. 1-24.

Yıldırım, A.; Ateş, M.; Akıncı, F.; Ross, T.; Selimen, D.; İşsever, H.; Erdim, A.; Akgün, M. (2005) 'Physician-Nurse Attitudes Toward Collaboration in Istanbul's Public Hospitals', International Journal of Nursing Studies 42, pp. 429-437.

Yukl, G.; Fu, P. P. (1999) ‘Determinants of Delegation and Consultation by Managers', Journal of Organizational Behavior 20, pp. 219-232.

\section{RÉSUMÉS}

In this qualitative study, physician-nurse relationships are examined under the light of existing literature by focusing on conflicts and their solutions at work. The main purpose of the study is to understand and interpret social relationships in one hospital organization in Turkey. According to focus group discussions, there are not only gender-based conflicts among physicians and nurses, but there are also conflicts due to the personal, professional, economic and gender-based inequalities of society. Therefore, psychological, cultural and structural factors play an important role, as do organizational and professional issues in the process of physiciannurse working relationships. Although in this study female physician-female nurse conflict challenged existing findings, nurses' interventions with respect to physicians' treatments and, thereby, ability to control power distribution, are also to be considered challenging findings. 
INDEX

Keywords : Conflict, Hospital., Nurse, Physician, Qualitative Study 